\title{
Sleep, Laziness and Making
}

Nik Wakefield

A connection between sleep, laziness and making can be established through an approach to both art and life that resists demonstrations of socially normative behaviour; and instead humdrums along in the minutia of the everyday where both art and life are causes without effects. In this article sleep is the actual dozing of Mladen Stilinović in his artist book Artist at Work (1978), a series of small photographs of the artist in bed, some with eyes closed, some with eyes open and some with his back to the camera. Sleep is also here a state of life that problematizes empiricist certainty and therefore encourages a kind of creative criticality that not only attempts to imagine the qualities of the unknown but also affords attention to low-profile relations between areas that at first seem unrelated. That critical gesture is related to a lazy methodology. By refusing to join in with spectacular expulsions of energy, lazy thinking slowly and unnoticeably roams across borders. This is Stilinović's only way to make art, as he writes in his 1993 text 'Praise of Laziness', and it is also a gesture of resistance to that performance of being busy that is endemic to contemporary capitalism.

Laziness here is not defined as not working but rather as not offering to the world a performed representation of being always at work. Laziness might include all kinds of effort and thought but it does so for no good external reason. If capital becomes a substitute for religion in that it gives meaning to action, 'laziness is courage for those who do not find salvation in work' (Miroslav Jilek 1977: 35 quoted in Stipančić 2007: 14). Although not working is a negative action in so far as it does not conform to capitalist orthodoxy, laziness can be a positive assertion of an individual's freedom to decide what to do with time. Laziness becomes a positive act. By denying competition laziness encourages cooperative ways of working together. Resistance to capitalism actualizes a collective subjectivity based not on brand loyalty but rather an inclusive loyalty to community, in the way that art critic Jan Verwoert has encouraged with his announcements to 'defy the pressure to perform' and later to 'dare to disappoint' (Verwoert 2010: 13 and 2014: 13). So while the word 'laziness' is not without trappings of the apparent negativity of non-action, here an enabling positive is added on. It is the prospect of small, slow, casual and easy; the prospect of which we in the West might still be afraid.

Being lazy is deciding not to participate in a belief in the inherent goodness of work and rather commit to activity without application. This is why sleep and laziness are crucial to art-making in the aftermath of modernist autonomy and more recent requirements for social impact or community engagement on one side and big-money galleries and high-profile institutions on the other, both of which rarely excuse art of its need for a reason to be. My text will take sleep and laziness as provocations to art-making. In doing so I will explore the work of Mladen Stilinovič and follow detours towards documentation and pollution. The undercurrent that sustains these questions is a validation of art as an activity of the world whose relation to life is that art is not a part of life but 
rather like or equal to life itself. Art is nether autonomous, dependent nor determined but rather all these and more, which is to say beyond the scope of my human intelligence's capacity for reason. Artmaking becomes as quotidian as rest. As obviously needed as sleep.

Laziness

'Praise of Laziness' is a provocation in a cool 568 words. The length of the text as voiced is important as it is too short to be a speech but too long to be a slogan. Likewise when read it is too short to be an essay and too long to be an epigraph. Mladen Stilinović read out the text in 1993 in Ghent at Gallery Opus Operandi. The year and location are significant to the piece as it occurred not long after Yugoslavia dissolved and independent countries such as Croatia and Slovenia were formed. The question Stilinović was partly addressing in the text is how this political change will affect artists like him, coming from cities like Zagreb or Ljubljana. However, he was reading the text in Belgium and clearly addressing a Western European audience with whom his relationship was now being reconsidered. Stilinović could draw a distinct boundary between Europe as the socialism of the East and the capitalism of the West only because he was now aware of that line's historicity and abstraction. He was considering the effects of the new political situation on art and suggesting a key that might solve a problem that was perhaps only apparent from his specific vantage point. The problem is the contemporary origin of art. Stilinović surprisingly makes the idiosyncratic argument that art only emerges from laziness.

In the first part of the text he explains that Western artists become instruments of capitalism because their labour consists of acts of production. Artworks that are objects to be traded are no longer artworks. For Stilinović there is a difference in kind between the art that is monetized and the art that has the purity of having no function. Those who would see this as nostalgia for the autonomy of modernist abstraction miss the point. Art without application, or lazy art-making, is not apolitical. Perhaps Stilinović is revealing that those art practices that made claims to autonomy had in fact only traded their allegiance from the social to the economic. More than only warning against the effects of the commodification of art, Stilinović is suggesting that laziness becomes the ultimate expression of freedom necessary in order to make sense of contemporary life with art. Lazy art is free because it is not working for anyone or anything. Art is excused and that is its value (Sabolović 2007).

Praise of Laziness ends with two quotes that reflexively play with authority in order to destabilize value. Stilinović misattributes 'work is a disease' to Karl Marx and then quotes himself and artist Vlado Martek saying 'work is shame'. First, Stilinović is playing with the idea that any quote followed by the name Karl Marx is something to be valued and trusted. This misappropriation is significant as an opposite of the typical Western postmodern appropriation that takes the work of another by the name of the self as Stilinović puts his own words into Marx's mouth. Second, giving a similar quote and attributing it to artists, one being himself, suggests that the erasure of the socialist East and its subsequent incorporation into capitalist West reconfigure the location of authority from 
political theory to artist. Taking this further, perhaps the idea is that name recognition, or celebrity, is the new authority. Value is in the mouths of those whose quotes are the most reproduced.

Reproduction operates socially through conformism, and conformism is the opposite of laziness in the framework that Stilinović suggests. If capitalist individualism is only masked conformism then laziness is crucial to the complex and important collective role of contemporary art, which is perhaps to actualize spaces of appearance and durations of creative becoming; to foster potential for difference.

\section{Sleeping Working Artist}

Other works by Mladen Stilinović made in the same year contextualize Praise of Laziness. There are paintings and works that hang on walls in galleries, such as Geometry of Cakes (1993), which is a pink sheet with several slices of cake and plates with strange slogans such as 'THE HARDEST WORK IS TO DO NOTHING' with the word 'DEATH' nearby and upside down. But there are also many small artist books, and these facilitate a more intimate connection. There is the small book Subtraction of Zeros (1993), with semi-transparent pages that begins with twelve zeros and takes one away each page until nothing is left, which playfully explores the ideas of quantity and nothingness, especially their roles in economic ideology.

Going further back, there is the book that contains a series of photographs of himself sleeping titled Artist at Work (1978), 'based on the idea that the work of an artist is hard to quantify' (Stipančić 2007: 14). Long before praising laziness, Stilinović was already aware of the complexity of the activities of art, and its uneasy relationship to labour. Sleep, so crucial to life, is for Stilinović also configured as a necessity for art. Probably his most famous book, I Have No Time (1979), repeats the title over and over again throughout the work. Beyond the obvious joke of needing to have the time to write or read I have no time over and over again, the book for Stilinović was a kind of 'bible', which I take to mean that the phrase was so commonplace that it manifested universal meaning (Stipančić 2007: 45). As a cliché the phrase becomes more a sign of social participation in the having of no time rather than a specific statement.

In the same decade Stilinović gave a sort of performance of his earlier book Foot--Bread Relationship (1977), which shows a loaf of bread being kicked against a wall, doing violence to an almost universally accepted icon of not only sustenance but even the body of Christ. In the 1979 performance at Amsterdam's De Appel Gallery the artist walked on to the stage with a loaf of bread and put up several photographs of the action, then placed the loaf of bread on the ground and looked at it. He was critiquing the practice of making a performance more for photographic documentation than for the live audience (Stipančić 2007: 13). Significantly, the role of documentation in art, as demonstration and commodification, ties into Stilinović's critical creativity. 
Documentation

One prevailing assumption regarding the documentation of performance is that doing so is necessary. There might even be an implicit belief in the inherent goodness of recording practices. As such the typical question is how to document performance. Asking how makes the assumption that performance should be documented. Perhaps one logical outcome of the McKenzian imperative to perform or else is to document or else. This might be a way for material to catch up with the experience economy. More and more performances make for more and more documents, until we are in up to our waists in images, texts, videos, three-dimensional virtual environments and any other nifty technology people might use to record a work of art. A new career as a professional documenter of performance is created. Young and less well-known artists of performance are required to become artists of documentation. But what is valuable in the archive is the aesthetic of the document, so historical visibility becomes based on how well a performance can be documented. Add to that, more pages, more ink, more hard drives and more shelf space needs to be made and used for all those documents.

This line of thinking might inspire an inversion to that typical question of how to document performance. If enough becomes enough, how do we not document performance? The implicit assumption that all documentation is moral also implies the inverse that an erasure would be immoral. So how could an artist ever consciously decide to not document a performance? Of course performing a negative is all but impossible. This would be tantamount to forgetting on purpose. To answer the question there will need to be a positive alternative to not documenting performance. As I have shown through the practices of Stilinović, contrary to the obligatory documentation of performance as an assumption of moral righteousness is the conceptual pose of laziness. This is the positive performance of doing the small whether or not it can be circulated. Performing whether it is documented or not might mean avoiding the trappings of possession whereby art is instrumentalized for capital. Setting aside the need to document valorizes the everyday activity of the artist over the productions and products the artist makes.

Possession and Pollution

Art as instrument of capitalism requires ownership and the practices surrounding possession include not only artistic but ecological ramifications. Stilinović critiqued the importance of ownership in his work History of Modern Art (1977), which took the most popular art history book at the time, H. H. Arnason's 1968 A History of Modern Art, and blacked out everything in it except the captions below the reproductions that explained which wealthy family or other purchased or donated the work of art (Stipančić 2007: 20). By erasing other information Stilinović highlighted how capitalism affects art. His work reveals an assumption that art relies upon either state or private funding to exist. Artists are merely service providers who only create when given the chance to. Stilinovič reveals the possessive 
capacities of objects and documents, as well as performances, to suggest that our cultural practices imply that art only exists if it can be owned. But in doing so Stilinovič is also revealing that artists do not have to participate in the possessive practices. As a whole his practice points to a disconnect between capitalism and art, through a critique of possession.

A similar critique of possession reveals the ecological implications of these practices. In his 2011 book Malfeasance: Appropriation through pollution?, Michel Serres explains how it is not only non-human animals that demarcate areas of ownership through bodily waste. Serres shows how our human species has developed a practice of ownership equally dependent on piss and shit, only now waste takes the forms of brand names and advertisements; constructions that make space into place. Serres argues that only a tenant's relation with the world would enable a non-combative state of living, structured around the power of the world, a 'cosmocracy' (Serres 2011: 84). We can live with the world without owning it. We can make art without it needing to be signed or bought. Creation does not require possession.

This idea of appropriation as pollution is timely in terms of the contemporary need to stop making waste or risk extinction. Clear links between consumption, production and waste provide options for less suicidal practices of life. The goal of over-abundance is replaced by trends towards moderation in developed countries, while enforced limitations of resources in the developing world show what is to come. A paradigm shift of our time might be a greater humility with regard to the limits of our species. There are simply not enough resources to go on as before. It is the same in the less significant realm of performance documentation, where there are also simply not enough resources to document everything and maintain the accessibility of those documents. In both the macro scale of climate and the micro scale of performance history, there is also not enough attention to remember everything. Learning the limits means understanding relations between processes of production, consumption and waste as aspects of ecology. Serres reveals the outcome of our habits of making place by showing that the normal way to own is to pollute. If that is true, and the only way to live is to stop polluting, it follows that the way to live is to stop owning. To return this ecological analysis to the realm of art, the best way to go on creating as an artist is to find ways to work with but not subordinate to possessive capitalism.

Anonymity and Reduction

If art is a way to explore new ways of living, as Zdenka Badovinac has explained (Badovinac 2008: 65), there are two strategies -- anonymity and reduction -- that some artists have used to eschew ownership. Joanna Zylinska argues persuasively for the positivity of reduction in her 2014 book Minimal Ethics for the Anthropocene. She posits an aesthetic of minimal impact as a necessary correction to the now obviously harmful notion of the necessity of growth. Solving the problem of how to create and do less at the same time might be one of the most provocative practical explorations of the Anthropocene. For examples of anonymity, while the suppression of the individual 
to God led to medieval plays being attributed to anonymous authors, a socialist critique of capitalism and its competitive individualism led, partially at least, to the formation of late twentieth-century Eastern European art collectives, known as New Art Practice, such as Gorgona, OHO, NSK, Laibach and Group of Six Artists, of which Stilinovič was a part. Their aesthetics were socio-political. As is clear in Croatian artist and filmmaker Goran Trubljak's quote I saw on the wall of the Ljubljana Museum of Contemporary Art Metelkova.
We stopped painting, we went out in the streets, we all did our own thing, whatever popped into our mind at the time. At the time, I was interested in making things I left unsigned in the street, a sort of discrete, anonymous actions, and I didn't care if people would recognize it as art. When I was doing that, I wasn't thinking of it as art, much less a specific form of art.

Like Stilinović what is crucial here is not that art is autonomous but that it emerges from autonomy. Although Trubljak was putting his art into public space the practice is not about marking owned territory. In Serres' framework, because the artworks are unmarked it is not appropriation and therefore not pollution. Even the pieces that include Trubljak's name are questioning whether he can even be called an artist or not, as opposed to assuming the role of the artist able to own and sell his works.

Of course these considerations are not unique to New Art Practice, and other artists had found the notions of possession and pollution to be useful ideas to understand the work of the artist. Appropriation through pollution in other contexts brought out the notion of waste. This idea highlights the prescience of one of Antonin Artaud's best textual artworks, 'All Writing Is Garbage'. The paradox of criticizing writing in writing makes Artaud as culpable as anyone else of the embarrassing assumption of having something to say. He exposes the power and therefore danger of meaning. As with other artists of his period such as René Magritte, Artaud reveals that the attribution of meaning is inherently linked to the determination of value and therefore structures of power, which easily become instruments of privilege and violence. Artaud explains that once writing is shared publicly it becomes waste, which Serres also self-reflectively refers to but more specifically, explaining that the letters of his name on the spine of the book are just as much pollution as the logo on the automobile that means it remains owned by its maker even after it is bought. Both Serres and Artaud reveal that ownership stinks, which is manifested through R. Mutt's urinal, or Marcel Duchamp's The Fountain (1917). It emits invisible stench through concept and even figures a fall through dotted holes that ends in a pile. The urinal highlights the invisible atmosphere surrounding ownership. Serres, Artaud, Duchamp and Stilinovič are sensitive to the not always positive effects of ownership and naming. They therefore expose appropriation to be neither innocent nor neutral. 
Conclusion

Mladen Stilinović adds to the general critique of ownership a specific critical position on aesthetic, political, economic and ecological regimes. That his art practice is perhaps easily discarded is the very reason why I have attempted to reveal its importance. Stilinovič is a crucial reminder of the pleasure of making without the requirements to promote and sell. His work proposes a thoughtful interaction with the world through art. What I want to stress is that Stilinovič's approach proposes that art and life are related by necessity, not cause and effect. Art-making can be as everyday as sleep. If we consider art-making as necessary to our everyday lives, solutions to issues about public funding and education immediately come into relief. But to keep with the smaller scale, the ecology of a day on Earth includes the rest that art can provide.

In this exploratory text I have attempted to synthesize notions around art-making and politics using sleep as a figure for encouraging modes of practice. Encouraging because sleep means necessity, but not so simply. Sleep is one of many bodily activities that lie troublingly along the boundary between controllable and automatic. Sleep is in many ways universal but also niggles curiosity because what happens during sleep is conceptually just out of reach. I have attempted to attend to face such difficult realms. I come away with a strange persistent idea of adaptation as being somehow relevant to all this. Adaptation as compromise, concession and affordance. Art adapts to the tune of the snoring multiplicity. If sleep is the action of non-action, sleep presents a key to turning negatives into positives. Art-making as the actualization of solutions to problems. Sleep, laziness and making as the fitness of the unimportant.

References

Artaud, Antonin (1992) 'All writing is garbage', in Susan Sontag (ed.) and Helen Weaver (trans.)

Antonin Artaud: Selected writings, Oakland: University of California Press, pp. 85--6. Also at http://aksioma.org/What-Is-the-Importance-of-Being, accessed 3 May 2015.

Badovinac, Zdenka (2008) 'What is the importance of being Janez?', in Janša, Janez, Janša, Janez and Janša, Janez (eds) NAME Readymade, Ljubljana: Aksioma and Museum of Modern Art, pp. 53--65.

Sabolović, Sabina (2007) 'I've Got Time: Interview with Mladen Stilinović', http://mladenstilinovic.com/interviews/ive-got-time/, accessed 3 May 2015.

Serres, Michel (2011) Malfeasance: Appropriation through pollution? trans. Anne-Marie FeenbergDibon, Stanford: Stanford University Press. 
Stilinović, Mladen (1993) ‘Praise of Laziness', http://mladenstilinovic.com/works/10-2/, accessed 1

May 2015

Stipančić, Branka (2007) 'Artist's books', in Branka Stipančić (ed.) Mladen Stilinović: Artist's books

1972--2006, Istanbul: Platform Garanti Contemporary Art Center and Eindhoven: Vanabbemuseum, pp. 6--27.

Verwoert, Jan (2010) Tell Me What You Want, What You Really, Really Want, Berlin: Sternberg Press.

Verwoert, Jan (2014) Cookie!, Berlin: Sternberg Press.

Zylinska, Joanna (2014) Minimal Ethics for the Anthropocene, Ann Arbor: Open University Press. 